\title{
iPads for Cognitive Skills in EFL Primary Classrooms: A Case Study in Saudi Arabia
}

\author{
Jawza Alshammari ${ }^{1,2}$, Ruth Reynolds ${ }^{2} \&$ Kate Ferguson-Patrick ${ }^{2}$ \\ ${ }^{1}$ University of Hail, Hail, Saudi Arabia \\ ${ }^{2}$ University of Newcastle, Newcastle, Australia \\ Correspondence: Jawza H. Alshammari, English Language Department, Hail University, Hail, Saudi Arabia.
}

Received: October 29, 2020

Accepted: December 7, 2020

Online Published: December 8, 2020

doi: 10.5539/elt.v14n1p13

URL: https://doi.org/10.5539/elt.v14n1p13

\begin{abstract}
This research study was designed to clarify the effectiveness of innovative technology use in order to develop cognitive skills in Saudi Arabia with particular focus on the use of iPads in English as a Foreign Language (EFL) classes. New technology approaches are continually being implemented in educational environments but there is often lagging analysis as to the effectiveness of these approaches. In the context under review the implementation of iPads represented a significant shift from using paper and pen to using a portable touchpad and digital pen. This qualitative study comprising observations, interviews and focus groups with teachers and students in four primary EFL primary classrooms in Saudi Arabia. It aimed to investigate any links between EFL teaching approaches, revised Bloom's Taxonomy of thinking skills and the use of iPads. The findings indicated an unevenness in the application of revised Bloom's Taxonomy in English instruction generally and most iPad teaching practices were represented at lower order thinking levels (Remember, Understand and Apply). Also, flexible use of iPads when teaching-learning EFL represented levels of revised Bloom's Taxonomy which aligns with specific roles of; teacher (T), teacher-student shared role (TS) and student (S) and plays a part in representing cognitive skills. These findings contribute to tablet devices use in language learning literature by highlighting the 'how' of EFL instruction based on revised Bloom's Taxonomy.
\end{abstract}

Keywords: revised Bloom's Taxonomy, EFL classrooms, English language skills, iPads, Saudi Arabia, classroom technology, teacher pedagogy

\section{Introduction}

The use of technology in education has improved education's effectiveness and has played a significant role in education by providing different types of activities and increasing the ease of access to information, to support educators in their teaching (Beetham \& Sharpe, 2013; Dias \& Victor, 2017; Sharpe, Beetham, \& De Freitas, 2010). The integration of technology has been increasingly utilised by teachers due to their desire to improve student learning and to increase their students' digital skills as well as to improve access to learning (Bower, 2017). As argued by Chun, Kern, and Smith (2016), 'Technology provides new ways for languages, cultures, and the world to be represented, expressed, and understood' (p. 76). At times the use of technology is mandated by systems and governments such as the case in Saudi Arabia whereby a recent 2017 report (Habash, 2017) claimed all Saudi schools will have tablets distributed for student use instead of books. Technology integration is considered a most important pedagogy by teachers in Saudi Arabia (Almalki, 2020) and it is only one country among many countries that depends on technology in many fields, especially in educational environments (Alharbi, 2020; Alresheed, Raiker, \& Carmichael, 2017). Given the importance of English as a global language in which individuals from diverse nations communicate via English (Bybee \& Fuchs, 2006), increasing importance has been assigned to teaching English as a foreign language in Saudi schools and so the use of technology to augment this teaching has also become very important. It is important to consider how to move beyond the use of technology itself to how technology actually enables teaching and learning.

The use of tablet devices has also been of interest in education with a large systematic review conducted by (Bower, 2017) showing that from 365 papers, published in the journal Computers and Education between 2015 and 2017, the use of mobile learning devices as a technology (including iPads, mobile devices and interactive technologies) being researched is around $15 \%$. Over the past few years this could have increased especially as tablet devices have been introduced into Saudi education settings and so probably also internationally and many schools were fast to 
implement them (New Education News, 2015). The most widely used of mobile learning devices in the classroom is the Apple iPad (Culén \& Gasparini, 2011; Lawrence, 2016) with studies showing that students and teachers claim they enhance teaching, learning and play (Culén \& Gasparini, 2011). Jeddah, a city in western Saudi Arabia, was quick to introduce iPads to their private schools rather than public schools (New Education News, 2015) and thus this study was designed to examine how this big shift in education has impacted teachers in private schools previously used to traditional ways of teaching. Primary schools were chosen for the study because the primary school years are regarded as the foundational stage for learning and for a child's later development. As such, the knowledge and skills that learners acquire in primary schools have an entirely different effect than learning that is acquired at later stages (Marshadi, 2011). Also, this stage of learning is regarded as a 'critical period' of learning the English language (Henderson \& Yeow, 2012) especially as these students have already been exposed to these devices in their homes as a means of entertainment, and so using them at school is possibly an adaption and not an innovation (Neumann, Merchant, \& Burnett, 2020).

Most research literature is focused on teachers' and students' perceptions towards the implementation of iPads. It is important to consider how to move beyond the use of technology itself to how technology actually enables teaching and learning (McKnight et al., 2016). Little attention has been paid to scrutiny of the current actual use of iPads in EFL classrooms and how this may align with the cognitive skills of revised Bloom's Taxonomy. An understanding of the value of iPads from the perspective of the development of cognitive thinking skills has the potential to better adapt the use of iPads and enhance these teaching-learning practices.

\section{Related Literature}

\subsection{Bloom's Taxonomy}

Bloom's Taxonomy was presented in 1956 by Bloom and other educators Engelhart, Furst, Hill and Krathwohl (Bloom, 1956) as an approach to organising learning and categorising educational goals. Bloom et al designed the Taxonomy as a set of three hierarchical models including cognitive, affective and sensory domains. This paper sheds light on the cognitive domain. The original Bloom's Taxonomy was intended to exchange items among educational institutions around the world as a criterion for measuring educational objectives (Krathwohl, 2002). The cognitive domain is comprised of six levels, including knowledge, comprehension, application, analysis, synthesis and evaluation. Anderson et al. (2001) updated the original framework and added significant changes to produce a revised Bloom's Taxonomy, again comprising six levels of cognitive domain, with a new vision of emphasis and changing from nouns to verbs, thus inferring a much more active approach to moving from Lower Order Thinking (LOT) to Higher Order Thinking (HOT). The first three levels of thinking in this new approach (LOT) required learners to remember, understand and apply their knowledge; the three higher levels of thinking (HOT) required learners to analyse, evaluate and create knowledge (see Figure 1).

The following figure (Figure 1) by Robyn (2014) clarifies the classification of Bloom's taxonomy in which the levels are given step by step in an ascending order from down to top (Köksal \& Ulum, 2018, p. 77). This diagram shows the updated revised Bloom's Taxonomy (Anderson et al., 2001).

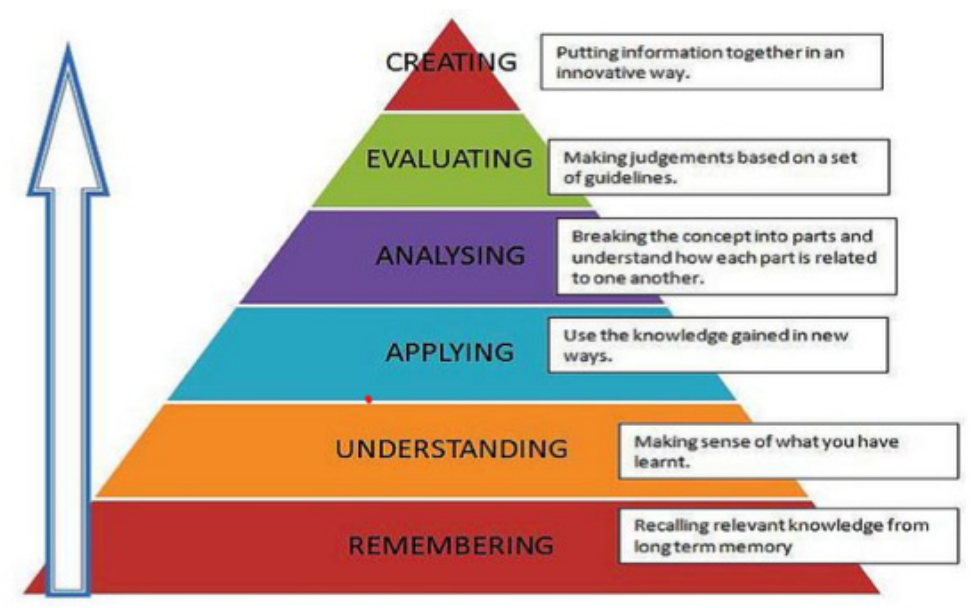

Figure 1. Blooms Taxonomy of Educational Objectives 


\section{Revised Bloom's Taxonomy of Educational Objectives}

In the twenty-first century, it is assumed that students should think deeply, and not only acquire knowledge (Mizbani \& Chalak, 2017) but also that teachers should drive their teaching towards categorising students' thinking at a high level. Bloom's Taxonomy is one of the frameworks used for defining thinking levels; it helps students to broaden the depth of their knowledge and learning and is a tool for enhancing students' critical thinking (Eber \& Parker, 2007). It also helps clarify critical thinking skills when integrated into classes and curriculums. Furthermore, it restores confidence in and awareness of assessment of thinking skills themselves.

Motivation and achievement in EFL learning are increased when higher-order thinking skills are the most emergent in classrooms (Alsowat, 2016) and teachers must therefore base their teaching on a high level of thinking. Even at higher education levels revised Bloom's Taxonomy can assist in clarifying the teaching, and the assessment of that teaching, required for higher cognitive levels in EFL learning (Baghaei, Bagheri, \& Yamini, 2020). Higher-cognitive thinking in students can be promoted by implementing higher-order thinking, as this helps learners to become more engaged and independent learners (Alnofal, 2018).

\subsection{Teaching English as EFL in the Light of Cognitive Skill Development}

Language teaching can be transformed from mere memorisation and repetition to more effective thinking skills by implementing Bloom's Taxonomy (Elfatihi, 2017). Thus, in English language classrooms, language should serve as a means of developing higher-order thinking skills; "students do not learn language for its own sake but in order to develop and apply their thinking skills in situations that go beyond the language" (Richards \& Burns, 2012, p. 110).

Teaching English as EFL through thinking skills for young learners is important and effort must be exerted by teachers (Tehrani \& Razali, 2018). Integrating thinking skills in teaching-learning language contributes learning language skills especially to young learners since it develops children's cognitive abilities and enhances learning outcomes (Ellis \& Brewster, 2014; Goh \& Taib, 2006; Tehrani \& Razali, 2018). This study reveals how levels of thinking can be represented in teaching-learning practices in an EFL context with young learners.

\subsection{A New Trend in Saudi Education: The Use of iPads}

In 2014, many Saudi Arabia private schools started using tablet devices for education, while in public schools, implementation of the policy of one tablet device per student was still in progress (Alarabyia Net, 2014). Tablet devices were introduced to supplement traditional paper-and-pen techniques in classrooms and some schools began implementing learning and teaching via tablet devices. More recently it is envisaged that this focus on e-technology using iPads will increase with newspaper reports pointing to plans by Saudi Education to distribute tablet devices to educational institutions, instead of books, in 2020 (Habash, 2017). There is a recent agreement signed between the Saudi Ministry of Education and a company specifically tasked to produce tablet devices for educational purposes. The ministry explained that educational structure will be changed in all schools in accordance with tablet devices implementation and the teachers' methods of dealing with educational material when use tablet devices inside and outside the classrooms (New Education News, 2015). Individual schools are still online due to COVID-19, so it is not clear if that has happened.

There are a number of recent studies in the area of teaching and learning English language skills by using iPads in Saudi Arabia in EFL classrooms, with studies more recently implemented such as those of (Al-Bogami \& Elyas, 2020; Al-Sharef, 2018; Albadry, 2017; Albiladi \& Alshareef, 2018; Alharbi, 2020). These studies all reached the same conclusion that tablet devices have a positive impact on teaching-learning practices. However, there is little investigation of the value of iPads in developing cognitive thinking, the focus of this particular paper. It is thus unclear as to how the use of an iPad used in EFL classrooms can support cognitive skills.

This paper seeks to determine how using iPads in the seven teaching language skills, the macro skills of listening, speaking, reading and writing, and the micro skills of grammar, vocabulary and spelling and pronunciation are categorised under cognitive thinking skills and in how using iPads in EFL classrooms represent thinking levels. A genuine contribution is hoped to be added to the research in the field of classroom technology. Additionally, the article seeks to fill a gap in the literature about the iPad's value in the light of cognitive skills of Bloom's Taxonomy. Furthermore, the methodology allows a way of testing theory qualitatively through using classroom observations and teacher and student interviews and focus groups and this methodological contribution can be applicable in other contexts (Rich, 2012). The paper can create a valuable contribution to researchers in other developing Arabic countries which intend to implement iPads in educational fields in the future (Al-Sharef, 2018). 


\subsection{Potential Benefits of iPads in Education}

One of the most significant change educational technology has made, is the manner in which it augments learning in flexible ways which align with learners' needs (Barari, RezaeiZadeh, Khorasani, \& Alami, 2020; Cavus, 2015). Also, there are possibilities of new and varied ways of teaching-learning practices which can be provided in implementing iPads in classrooms (Jahnke, Bergström, Mårell-Olsson, Häll, \& Kumar, 2017). It has also been revealed that iPads provide opportunities for enhancing roles of the teacher and student (Curtin \& Tarnow, 2013). Furthermore, student-centred instruction is one of the main benefits of iPads in education. It is a form of active learning that focuses on self-pacing which invites students to create, produce and consume knowledge (Çubukçu, 2012). Active learning was promoted in learning language when using iPads in classrooms (Gabarre, Gabarre, Din, Shah, \& Karim, 2014) and this aligns with the need of 21 century (Gitsaki, Robby, Priest, Hamdan, \& Ben-Chabane, 2013). Abundant research has been conducted in the field of technology-enhanced student-centered teaching and learning. iPad use in education has been confirmed as effective tools in enhancing student-centred instruction (Homma, 2015; Karsent \& Fievez, 2013; Lu, Ottenbreit-Leftwich, Ding, \& Glazewski, 2017; Moon, Wold, \& Francom, 2017). However, the 'how' of role of teacher or/and student-centred implementation of iPads in EFL classes have not been yet been determined in the literature and the degree to which this might relate to Bloom's Taxonomy is also a gap in the research literature.

\section{Research Questions}

Q1: When examining classrooms in Saudi Arabia, to what extent do teaching English language skills using iPads have relevance to the cognitive levels of revised Bloom's Taxonomy?

Q2: How do the different ways of using digital technologies with iPads when teaching English language skills in Saudi Arabian classrooms represent the different cognitive levels of revised Bloom's Taxonomy?

Q3: How do teachers and students differ in their use of iPads in the classroom in selected Saudi Arabian classrooms in relation to the cognitive levels of revised Bloom's Taxonomy?

\section{Methodology}

The current study was a qualitative case study based on both inductive and deductive approaches. Themes, patterns and categories were built from the "bottom up" and then checked against the data and current theories (Creswell, 2013). While searching for patterns inductively around the overall impact of iPad in EFL classrooms, including barriers and opportunities in the use of iPads, the researchers found patterns related to how iPad usage represented the critical thinking levels associated with revised Bloom's Taxonomy. In many cases it was evident in the ways the teachers described the activities and so seemed to be an underlying focus for some of their work. It was decided to pursue this more rigorously.

The researcher, who as a woman cannot access boys' schools, attended four international girls' elementary schools in Jeddah, in the Kingdom of Saudi Arabia. The data was elicited from three sources; field notes taken in EFL class observations (eight separate classroom observations undertaken); individual interviews with eight teachers after classroom observations; and separate focus groups meetings conducted with students (five groups of five) and teachers (four groups of three). Upon scrutiny of all the data collected from these sources, data related to revised Bloom's Taxonomy represented $23 \%$ of the data in total. The instances of a cognitive level, in the way the teaching was conducted and/or in the way the teachers and students perceived their teaching, was then linked to the Macro and Micro skills of EFL teaching.

\subsection{Data Analysis}

The data was first imported and analysed using the qualitative data analysis software NVivo 12 to enable detailed microanalysis. NVivo has been shown to improve the accuracy of qualitative studies and facilitate analysis by quickly recognising the coding and node structures (Zamawe, 2015). The data was analysed by reviewing transcripts of activities and actual teaching for both Macro language skills (listening, speaking, reading and writing) and Micro language skills (grammar, vocabulary and spelling, and pronunciation) while using iPads. Then data from the interviews and focus groups was added into NVivo with patterns and themes generated and given to each data set following the way of thematic analysis by Braun and Clarke (2006). Thus, firstly the field notes of observations; and the interviews and focus groups were categorised based on language skills. Then, as a result of a lot of data being seen to have relevance to revised Bloom's Taxonomy, closed coding was applied based on the six cognitive levels of revised Bloom: Remember, Understand, Apply, Analyse, Evaluate and Create based on (Anderson et al., 2001) revised Bloom's Taxonomy of Cognitive Domain. This revised Bloom's Taxonomy coding resulted in being $23 \%$ of all the data, so it was a significant theme. Descriptive analyses in the form of frequencies and percentages were used to represent the extent of coverage at each level for each language skill. The 
researchers then mapped the types of activities observed and mentioned to the levels of thinking. The first research question is based on actual observed classes only. The second and third research questions are based on observed classroom activities, teacher interviews, and focus groups of teacher and students.

\section{Results}

The data obtained through observations, interviews and focus group meetings was analysed based on the revised Bloom's Taxonomy hierarchy of the six levels (Remember, Understand, Apply, Analyse, Evaluate and Create). All the data was analysed based on descriptive frequencies and percentages.

\subsection{English Language Skills Based Revised Bloom's Taxonomy}

This process was designed to answer Research Question 1; When examining classrooms in Saudi Arabia, to what extent do teaching English language skills using iPads have relevance to the cognitive levels of revised Bloom's Taxonomy? Classroom observation data only was used.

The following tables (see Tables 1 and 2) demonstrate the connection between how the Macro and Micro English language skills are associated with the cognitive skills of revised Bloom's Taxonomy.

\subsubsection{Macro English Language Skills}

The following Table 1 is related to the four basic English language skills observed in classrooms. Productive skills require some form of language output (speaking and writing), and receptive skills require receiving information (listening and reading). These skills were analysed based on the frequencies and percentages of coverage in revised Bloom's Taxonomy.

Table 1. Percentage of time using MACRO skills associated with revised Bloom's Taxonomy

\begin{tabular}{llllll}
\hline & & Listening & Speaking & Reading & Writing \\
\hline $\begin{array}{lllll}\text { Lower Order } \\
\text { thinking }\end{array}$ & Remember & $54.5 \%$ & $25 \%$ & $41.2 \%$ & $21.4 \%$ \\
& $\begin{array}{l}\text { Understand } \\
\text { Apply }\end{array}$ & $18.2 \%$ & $12.5 \%$ & $23.5 \%$ & $14.3 \%$ \\
$\begin{array}{l}\text { Total Percentage of } \\
\text { each macro skill }\end{array}$ & & $18.2 \%$ & $25 \%$ & $5.88 \%$ & $35.7 \%$ \\
$\begin{array}{l}\text { (LOT) } \\
\begin{array}{l}\text { Higher Order } \\
\text { thinking }\end{array}\end{array}$ & $\begin{array}{l}\text { Analyse } \\
\text { Evaluate }\end{array}$ & $90.9 \%$ & $62.5 \%$ & $70.6 \%$ & $71.4 \%$ \\
& Create & 0 & & & \\
$\begin{array}{l}\text { Total Percentage of } \\
\text { each macro skill }\end{array}$ & & $0.1 \%$ & $12.5 \%$ & $17.6 \%$ & 0 \\
(HOT) & $9.1 \%$ & 0 & $5.88 \%$ & 0 \\
\hline
\end{tabular}

The table indicates that most lower order activities occur in listening activities with the most prominent higher order thinking activities occurring in speaking. Both reading and listening dominate the remembering level and writing occurs more often in the applying level. It is interesting that in the highest order thinking activity of creating most activities involve either speaking or writing.

\subsubsection{Micro English Language Skills}

The following Table 2 focuses on the three secondary (Micro) English language skills of grammar, vocabulary and spelling, and pronunciation that were observed in classrooms. They were analysed based on revised Bloom's Taxonomy. 
Table 2. Percentage of time using MICRO skills associated with revised Bloom's Taxonomy

\begin{tabular}{lllll}
\hline & & Grammar & Vocabulary and Spelling & Pronunciation \\
\hline $\begin{array}{llll}\text { Lower Order } \\
\text { thinking }\end{array}$ & $\begin{array}{l}\text { Remember } \\
\text { Understand }\end{array}$ & $40 \%$ & $33.3 \%$ & $18.2 \%$ \\
& Apply & $13.3 \%$ & $9.52 \%$ & $9.1 \%$ \\
\hline $\begin{array}{l}\text { Total Percentage } \\
\text { of each Micro } \\
\text { skill (LOT) }\end{array}$ & $26.7 \%$ & $28.6 \%$ & $54.5 \%$ \\
\hline $\begin{array}{l}\text { Higher Order } \\
\text { thinking }\end{array}$ & $\begin{array}{l}\text { Analyse } \\
\text { Evaluate }\end{array}$ & $80 \%$ & $71.4 \%$ & $81.8 \%$ \\
& Create & $6.67 \%$ & $14.3 \%$ & \\
\hline $\begin{array}{l}\text { Total Percentage } \\
\text { of each Micro } \\
\text { skill (HOT) }\end{array}$ & $13.3 \%$ & $9.5 \%$ & 0 \\
\hline
\end{tabular}

This table clearly demonstrates that in the micro skills of English language lower order thinking activities dominate, with both grammar and pronunciation dominating the lower order teaching and learning activities. When students are asked to use vocabulary and spelling, they are more likely to move into higher order thinking although this only occurs in less than $30 \%$ of the activity time.

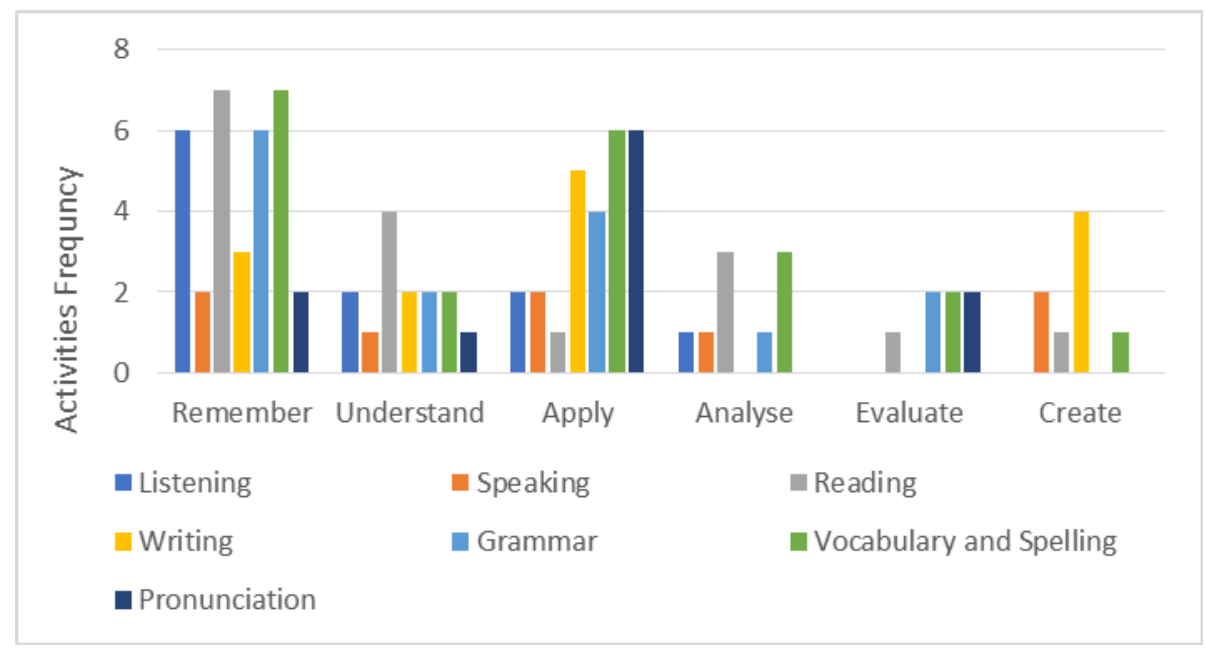

Figure 2. A comparison of percentages for all 97 separate language skills activities observed in classroom observations based on revised Bloom's Taxonomy

The above chart shows the numbers of activities related to the six levels of remembering, understanding, applying, analysing, evaluating and creating for language skills. Eight classroom observations were conducted by the researcher for all language skills of listening, speaking, reading, writing, grammar, vocabulary and spelling, and pronunciation were used to compile this data. 97 activities in all were noted across the eight observations. From this chart, it can be clearly understood that the highest number of activities are related to reading, and vocabulary and spelling at the remembering level (7). However, the activities for speaking and pronunciation are lowest at this level (2). At the understanding level, reading activities are highest (4), while speaking and pronunciation have the lowest number of activities (1). At the applying level, the highest number of activities is in vocabulary, and spelling and pronunciation (6), there are (2) activities related to listening and speaking each, while activities related to reading are the lowest (1). At the analysing level, there are three activities each in reading, and vocabulary and spelling, and one activity in listening, speaking and grammar, whereas there are no activities in pronunciation or writing.

At the evaluating level, there are two activities each in grammar, vocabulary, and spelling and pronunciation, and one activity in reading, while there is no activity for listening, speaking and writing. Finally, at the creating level, the highest number of activities are in writing (4), whereas there are no activities related to listening, grammar or pronunciation. Overall, when we make a comparison between the six levels, the remembering level has the most 
activities (33), the applying level is second highest with 25 activities, the understanding level is third highest with 14 activities, while the remaining levels, analysing, evaluating and creating, contain less than ten activities each.

\section{2 iPad Activities Used in Classrooms Based on Revised Bloom's Taxonomy}

The researchers examined all the data associated with revised Bloom's Taxonomy and noted the different teaching activities undertaken and commented upon by teachers and students. This process was designed to answer Research Question 2; How do the different ways of using digital technologies with iPads when teaching English language skills in Saudi Arabian classrooms represent the different cognitive levels of revised Bloom's Taxonomy?

\subsubsection{Macro Skills Activities Based on Revised Bloom's Taxonomy}

The six levels of thinking are represented by practicing teaching and learning EFL using iPads in the basic language skills (Macro), listening, speaking, reading and writing as described below in Table 3. Some descriptions of the activities in use (marked by a star) are provided below.

Table 3. Activities associated with MACRO language skills linked to revised Bloom's Taxonomy

\begin{tabular}{|c|c|c|c|c|c|c|}
\hline Macro skills & Remember & Understand & Apply & Analyse & Evaluate & Create \\
\hline \multirow[t]{4}{*}{ Listening } & Video & $\begin{array}{l}\text { Digital } \\
\text { Dictionary* }\end{array}$ & \multirow[t]{4}{*}{$\begin{array}{l}\text { Digital } \\
\text { Notebook* }\end{array}$} & \multirow[t]{4}{*}{$\begin{array}{l}\text { Analysing } \\
\text { language Usage }\end{array}$} & \multirow[t]{4}{*}{$\mathrm{N} / \mathrm{A}$} & \multirow[t]{4}{*}{$\mathrm{N} / \mathrm{A}$} \\
\hline & Lecture & $\begin{array}{l}\text { Drill and Practice } \\
*\end{array}$ & & & & \\
\hline & $\begin{array}{l}\text { Oral } \\
\text { Translation }\end{array}$ & & & & & \\
\hline & $\begin{array}{l}\text { Recall } \\
\text { Information }\end{array}$ & & & & & \\
\hline \multirow[t]{4}{*}{ Speaking } & \multirow[t]{2}{*}{ Flashcards } & \multirow{2}{*}{$\begin{array}{l}\text { Digital } \\
\text { Dictionary }\end{array}$} & \multirow{4}{*}{$\begin{array}{l}\text { Digital } \\
\text { Notebook* }\end{array}$} & \multirow{4}{*}{$\begin{array}{l}\text { Analysing } \\
\text { Language Usage* }\end{array}$} & \multirow[t]{4}{*}{ N/A } & Project \\
\hline & & & & & & Video \\
\hline & \multirow[t]{2}{*}{ Presentation } & \multirow{2}{*}{$\begin{array}{l}\text { Drill and } \\
\text { practice* }\end{array}$} & & & & Creation \\
\hline & & & & & & $\begin{array}{l}\text { Video } \\
\text { Simulation }\end{array}$ \\
\hline \multirow[t]{6}{*}{ Reading } & \multirow[t]{2}{*}{ Presentation } & \multirow[t]{2}{*}{ Translation } & \multirow{6}{*}{$\begin{array}{l}\text { Digital } \\
\text { Notebook* }\end{array}$} & \multirow{6}{*}{$\begin{array}{l}\text { Analysing } \\
\text { Meaning* }\end{array}$} & \multirow{6}{*}{$\begin{array}{l}\text { Self-Assessment* } \\
\text { Self-Feedback }\end{array}$} & Project \\
\hline & & & & & & \\
\hline & Digital books & $\begin{array}{l}\text { Define and } \\
\text { Search }\end{array}$ & & & & \\
\hline & \multirow[t]{3}{*}{ Lecture } & $\begin{array}{l}\text { Digital } \\
\text { Dictionary }\end{array}$ & & & & \\
\hline & & Presentation & & & & \\
\hline & & $\begin{array}{l}\text { Traditional } \\
\text { instruction and } \\
\text { lecture }\end{array}$ & & & & \\
\hline \multirow[t]{10}{*}{ Writing } & \multirow[t]{2}{*}{ Video } & Digital & Flipped & \multirow[t]{10}{*}{ N/A } & \multirow{10}{*}{$\begin{array}{l}\text { Analyse Online } \\
\text { Resources * }\end{array}$} & Project \\
\hline & & Dictionary & Classroom* & & & Research \\
\hline & \multirow[t]{2}{*}{ Brainstorming } & & Classification & & & \\
\hline & & Traditional Word & & & & \\
\hline & \multirow{6}{*}{ Flashcards } & \multirow[t]{6}{*}{ Translation } & Oral & & & \\
\hline & & & Discussion & & & \\
\hline & & & $\begin{array}{l}\text { Find the Fib } \\
\text { PowerPoint }\end{array}$ & & & \\
\hline & & & $\begin{array}{l}\text { Drill and } \\
\text { practice }\end{array}$ & & & \\
\hline & & & Digital & & & \\
\hline & & & Notebook & & & \\
\hline
\end{tabular}

Note. N/A refers to activities could not be determined. 


\section{Listening}

Digital dictionaries

When teachers use iPads in listening class, they ask students to find word meanings in digital dictionaries such as the Merriam-Webster dictionary. It was observed that the teacher presents words on the board and asks students to find the meanings, which represents the understanding level of thinking.

Drill and practices

Students were asked to do a fill-in-the-gaps activity based on the dialogue presented at the beginning of the class. This activity represents the understanding level of thinking.

Digital notebook

Teachers use the iPad as notebook, asking students to write a topic based on the lesson topic. This represents the applying level of thinking.

\section{Speaking}

Drill and practice

Teachers use online activities in the speaking class. Students were asked to do word-meaning activities in groups. This represents the understanding level of thinking.

Digital notebook

iPads were used by the students as digital notebooks. They were asked to write a descriptive text and then present it orally to the class. This represents the applying level of thinking.

Analysing language usage

In the speaking class, students used different iPads apps to focus on many parts of words, such as American or British accents, and synonyms and antonyms, which represents the analysing level of thinking.

....We are focusing on many parts of words, such as whether it is an American or British accent, and on synonyms and antonyms .... T5

\section{Reading}

Digital Book

In the observed reading class, students were asked to read a poem about winter glaciers from an eBook online source, which represents the remembering level.

...I always use group work. I divide the class into groups, and each group has a leader. Each leader is responsible for reading a paragraph to her classmates in her group, and then she allows five minutes for her classmates to read afterwards. Each leader is responsible for explaining to the class the main ideas of the paragraph...T6

Digital notebook

In representing the applying level, teachers ask students to write a sentence about how the narrator compares herself to a river and then discuss with their partner, using their iPads as a notebook.

Analysing language usage

Analysing meanings in reading from different digital sources is one of the activities that represents the analysing level.

One helps in find out the meanings, while the other one finds extra information to answer questions. Then, they discuss and share altogether... FGT1

Self-assessment

In representing the evaluating level, students use a function of the iPad to evaluate themselves in reading: .... There is what is called a fluency test in Natural Reader, and they can test their level of reading fluency.... FGT2

\section{Writing}

Flipped classroom

The teacher plays the video again as an example to students for how they might write about their best friend in a similar way that presented in the video. This represents the applying level. 
Analyse online resources

In representing the evaluation level, online resources through iPads were used in analysing some information.

...After the mind map and brainstorming, students can use learning resources such as online books and short articles. In addition, discussion is a good technique I usually use. By dividing the class into groups, each group can discuss with the others.... T3

\subsubsection{Micro Skills Activities Based on Bloom's Taxonomy}

The six levels of thinking are represented by practicing teaching and learning EFL using iPads in the secondary language skills (Micro), grammar, vocabulary and spelling, and pronunciation as categorized below in Table 4 .

Some descriptions of the activities in use in Micro EFL teaching (marked by a star) are provided below.

Table 4. Activities associated with MICRO language skills linked to revised Bloom's Taxonomy

\begin{tabular}{|c|c|c|c|c|c|c|}
\hline Micro skills & Remember & Understand & Apply & Analyse & Evaluate & Create \\
\hline \multirow[t]{5}{*}{ Grammar } & Games & Video* & $\begin{array}{l}\text { Digital } \\
\text { Dictionary }\end{array}$ & $\begin{array}{l}\text { Analysing } \\
\text { language Usage }\end{array}$ & Self-Evaluation & $\begin{array}{l}\text { Games } \\
\text { Creation }\end{array}$ \\
\hline & Test & Online Sources & Games & & Survey & \\
\hline & Brainstorming & Think-Pair-Share & Search & & & \\
\hline & $\begin{array}{l}\text { Flipped } \\
\text { Classroom* }\end{array}$ & Classification & Art and Craft & & & \\
\hline & Search & & & & & \\
\hline \multirow[t]{9}{*}{$\begin{array}{l}\text { Vocabulary } \\
\text { and Spelling }\end{array}$} & Oral Instructions & $\begin{array}{l}\text { Flipped } \\
\text { Classroom* }\end{array}$ & Drill Practice* & $\begin{array}{l}\text { Analysing } \\
\text { Language Usage* }\end{array}$ & & \\
\hline & Tests & Video & $\begin{array}{l}\text { Crossword } \\
\text { Puzzles }\end{array}$ & Survey & & \\
\hline & Finding & Define and & Fill-in-the-Blanks & & & \\
\hline & Meanings & Search & Dictionary & & & \\
\hline & Video & Dictionary & Quizzes & & & \\
\hline & $\begin{array}{l}\text { Recall } \\
\text { Information }\end{array}$ & $\begin{array}{l}\text { Digital } \\
\text { Notebooks }\end{array}$ & Games & & & \\
\hline & Information Gap & & & & & \\
\hline & Online Quizzes & & & & & \\
\hline & $\begin{array}{l}\text { Flipped } \\
\text { Classroom }\end{array}$ & & & & & \\
\hline Pronunciation & & Presentation & $\begin{array}{l}\text { Drill and Practice } \\
\text { Classification }\end{array}$ & $\begin{array}{l}\text { Analysing } \\
\text { Language Usage* }\end{array}$ & & \\
\hline
\end{tabular}

\section{Grammar}

Flipped classroom strategy

Lecturing was used in explaining a video previously sent to students to represent the remembering level:

.... For Homework, I can go to the previous video on (TAWASUL) and have a look at the video sent by my teachers. This helped me to revise the grammatical forms and reminds me how to use it.... FGS5

Video

The teachers use videos to present grammatical forms to their students, which represents the understanding level.

... a live example on their different grammatical apps on their own iPads and attractive animations in grammatical apps that can explain some grammatical forms without the need to translate into Arabic.... T4

\section{Vocabulary and Spelling}

Flipped classroom

In representing remembering, teachers send videos from their homes as a flipped classroom strategy. 
.... For the flipped classroom, I always send them a video before, then when I come to the class the next day, they already know what they have to do, and they give me the meanings of the words instead me giving them the meanings.... T4

Drill and practice

It was observed that students were asked to write the words in the blanks as they were read aloud when the teacher clicks a word to be pronounced, which represents the applying level. Also, students were asked to look at the list of words to correct spelling mistakes as another activity at the applying level.

Analysing meanings

In representing the analysing level, students were asked to use any dictionary app for given words. Fryer strategy were used. They were asked to find the meaning, synonyms, antonyms and part of speech, then put it into a sentence. In terms of analysing meanings with iPad dictionaries, one excerpt emerged: "There is also Merriam-Webster, which gives synonyms and antonyms and also ... parts of speech. Sometimes they compare the results they have from each app" ...T1.

\section{Pronunciation}

Drill and practice

Drill and practice appeared at the applying level many times. First, a short story is given to each group on an iPad, then students were asked to find as many long u sounds in words as possible. Secondly, students were asked to give their own examples of long u sounds. Thirdly, students were asked to decode the words presented in PowerPoint with long u sounds. Finally, the teacher asked the students to do a missing-sounds activity in PowerPoint. Finally, the activity in PowerPoint was presented to the students, and they were asked to write the spelling of the word on their iPads under the spelling pattern to which it belonged, such as /u:/ spelled oo, u-e, ou, ew, ui or o-e.

Language usage

Students mentioned that iPads helped them to get deeply into language variations between US and US pronunciation. This activity represents the analysing level.

.... I always go to another device and app to compare its pronunciation, because sometimes apps pronounce the word wrongly.... FGS3

\subsection{Clarifying Teaching-Learning Roles Based on Revised Bloom's Taxonomy}

This analysis clarifies who drives the learning and teaching activities based on three categories and the revised Bloom's Taxonomy. The learning and teaching activities were divided into activities primarily directed by the teacher; activities jointly directed by the teacher and the students; and then activities driven primarily by the students. They were categorised according to the levels associated with the cognitive dimension of revised Bloom's Taxonomy.

This process is linked to RQ3: How do teachers and students differ in their use of iPads in the classroom in selected Saudi Arabian classrooms in relation to the cognitive levels of revised Bloom's Taxonomy?

Table 5. Leadership of teaching and learning activities associated with revised Bloom's Taxonomy: MACRO Skills

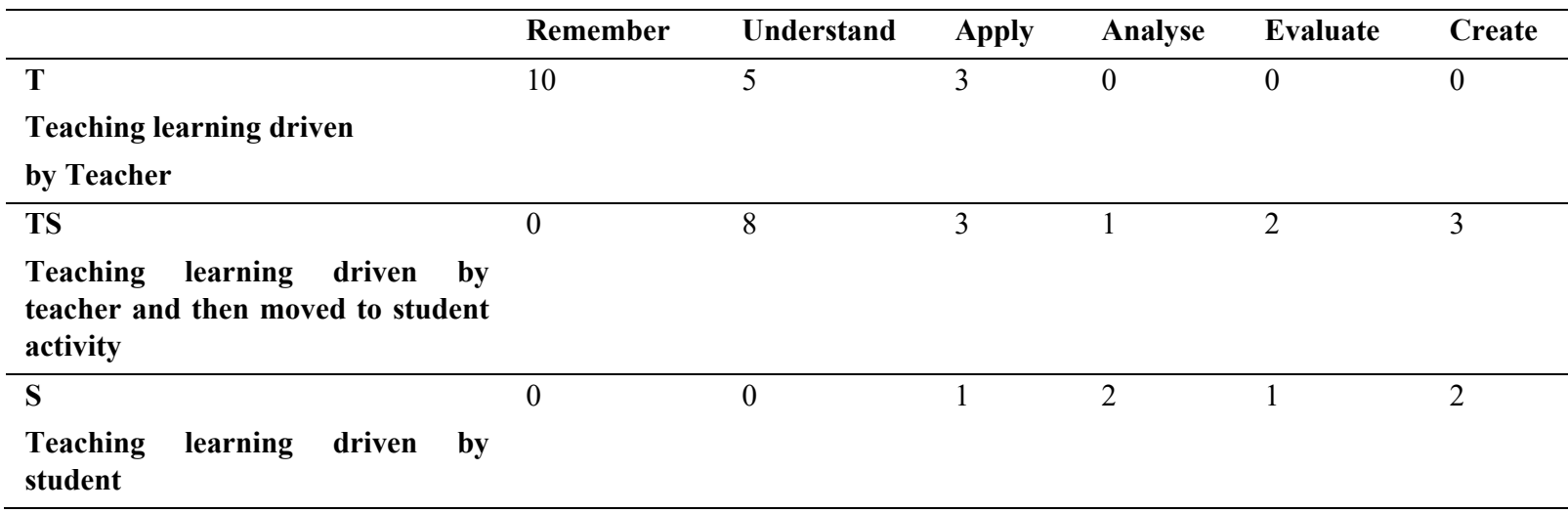

This table clearly shows that when the teacher controls the lesson, they have students involved in lower order activities. 18 activities are teacher led and are LOT. There are no teacher led activities which require students to use HOT skills. 17 activities are T led and then move to student driven. In the student driven activities, they are 
more likely to be of a HOT level. This suggests that perhaps if teachers allow students to take more control of the lesson then they will develop the students' cognitive skills and move them into HOT. It also suggests that when teachers are involved higher order thinking can occur more readily (Baghaei et al., 2020). The lack of teacher engagement in higher order thinking could be an issue if teachers delegate too much engagement to student focussed technology Apps and not build cognitive levels through many different Apps.

Table 6. Leadership of teaching and learning activities associated with revised Bloom's Taxonomy: MICRO Skills

\begin{tabular}{lllllll}
\hline & Remember & Understand & Apply & Analyse & Evaluate & Create \\
\hline $\begin{array}{l}\text { T } \\
\text { Teaching learning driven }\end{array}$ & 2 & 5 & 0 & 0 & 0 & 0 \\
by Teacher & & & & & \\
\hline $\begin{array}{l}\text { TS } \\
\text { Teaching learning driven by } \\
\text { teacher and then moved to } \\
\text { student activity }\end{array}$ & 11 & 8 & 11 & 3 & 1 & 0 \\
\hline $\begin{array}{l}\text { S } \\
\text { Teaching learning driven by } \\
\text { student }\end{array}$ & 0 & & & & & \\
\hline
\end{tabular}

This table indicates that when teacher controls the lesson, their role represents lower order activities. There are 7 activities led by teacher in LOT. There are no activities represent HOTs in activities led by teacher. 30 activities represent LOT are teacher led and then moved to students driven activities while only 4 activities that require students to use HOT skills. In the last part, it shows that HOT are represented more than LOT levels by activities driven by students only. This also suggests, if students control the lesson, they will develop their cognitive skills and move to HOT rather than LOT. However, the small number of times they do this indicates that they may need more assistance to take this active role.

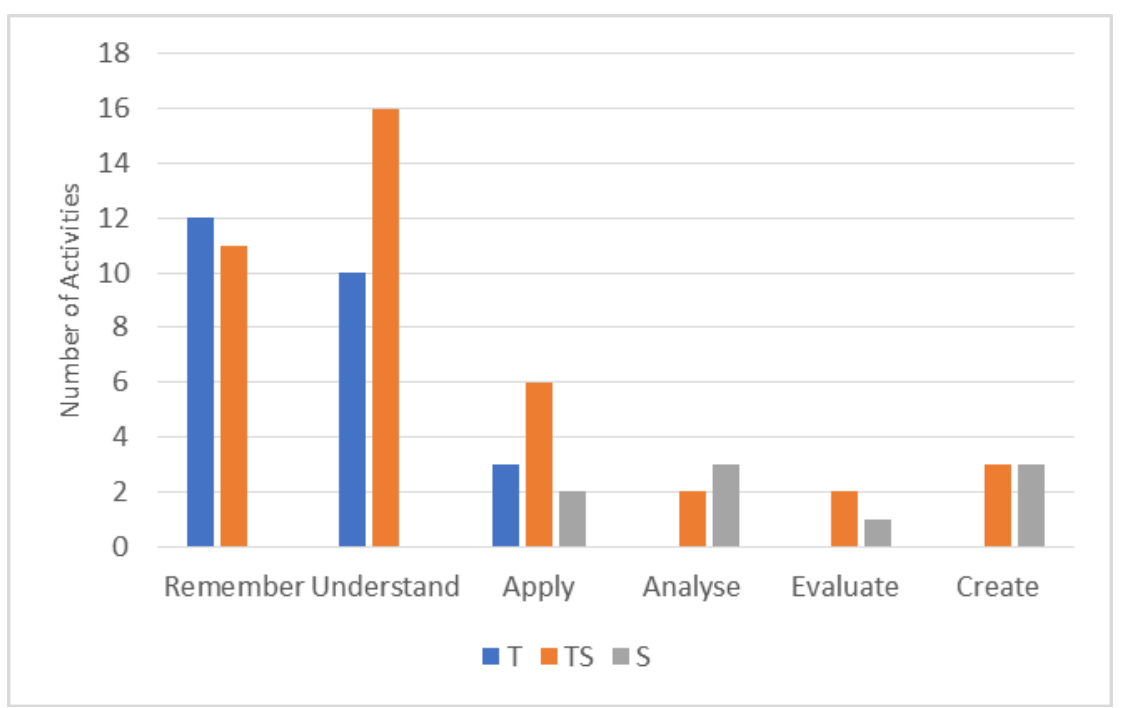

Figure 4. Leadership of teaching and learning activities associated with revised Bloom's Taxonomy in all language skills

This table shows that the three LOT are most represented by the role of teacher T when she controls the lesson. They involve their students in lower order activities among all English language skills. It shows non-occurrence of teacher led activities involve students using HOT. Activities led by teacher then moved to student TS are represented by an unbalanced tendency through lower and higher order thinking skills. It is showed that TS role is linked more with LOT than HOT. For student driven activities S, it is clearly showed HOT are represented more than LOT among all language skills. To summarise, S, TS and T are more than less involved in HOT activities.

\section{Discussion}

This study was framed by three angles of inquiry around revised Bloom's Taxonomy: it asked how often revised Bloom's cognitive skills are evident, and in what capacity, when observing and discussing with teachers and students in the iPad driven EFL classroom. The interpretation of the results above answers these important 
questions. A mixed descriptive analysis based on frequency and percentage with a thematic analysis was conducted to analyse the data.

According to the first question that investigates how often revised Bloom's Taxonomy levels are represented in the seven EFL skills, the findings suggest low levels are represented in all language skills. This finding agrees with $\mathrm{Wu}$ and Wang (2015) who examined the revised Bloom's Taxonomy in computer-assisted language learning and found that class activities are often distributed in the first three level domains of the revised Bloom's Taxonomy rather than higher-order thinking levels. Furthermore, these findings are in line with Alnofal (2018), who focused on observing Saudi EFL reading class activities based on traditional teaching methods. Our study resembles the Alnofal study in that some non-occurrence of higher-order thinking levels was evident in teaching and learning EFL. Also, it has been noticed that the occurrence of all language skills mostly covering lower-order thinking levels evident in our study is similar to Köksal and Ulum (2018) study, which revealed all language skills questions and assessment tools cover lower-order thinking skills rather than higher ones, with an absence of some higher-order levels.

Concerning the second question, which answers how teachers and students use iPads in representing revised Bloom's cognitive thinking skills, the findings are linked to studies focused on technology-enhanced language learning in general and how a variety of strategies, uses, methods and ways can accomplish thinking levels by technology, such as that by Rim (2019). Additionally our study resembles the e-learning study of virtual classes by Barari et al. (2020) in how the activities undertaken represented the first three LOT skills. They represent remembering level by google use, listen to online sources and digital dictionaries use. Pre-organised activities and activities based on mistakes and gaps enhanced understanding level. In empowering applying level, they employed associative activities and drill and practice (Barari et al., 2020).

The research literature indicates that the use of technology in classes often represents enhancement rather than transformation (Keane, Keane, \& Blicblau, 2016). It enhances teaching efficiency rather than transforming instruction which means, in most cases, technologies in classrooms are used as a replacement of paper and pen tasks (Cherner \& Curry, 2017). Technology use is a powerful addition in the teaching and learning process when used effectively (McKnight et al., 2016) as well as a pedagogical game changer when implemented efficiently (Cochrane, Narayan, \& Oldfield, 2013).

As indicated in our study and by others teachers should consider the need for constructing higher levels in their EFL classes in accordance with using iPads for this purpose. It would be useful to provide some support for teachers to focus on higher-order skills rather lower-order levels in EFL (Alnofal, 2018; Khorsand, 2009). Teachers pointed out that they lack training and are not well prepared when introducing technology in classrooms (Almalki, 2020). They may be not aware of the role of cognitive thinking skills in teaching (Tehrani \& Razali, 2018). Furthermore, they may find themselves restricted when using iPads with specific uses and certain Apps that may suit only lower order thinking levels rather higher levels (McKnight et al., 2016).

According to the third question, in our study, three roles of teaching and learning English as EFL using tablet devices have been seen. Firstly, teacher driven teaching with the traditional method of 'sage on the stage' as put by King (1993). The teacher merely transmits knowledge to their students with a passive role of students (T). The second role is when teachers led activities and then moved to student's taking more control of the activity (TS). The third role is when students drive the lesson and activities on their own. The first two roles represented mainly LOT rather than HOT levels in revised Bloom's Taxonomy while the role of student in terms of driving the lesson represented HOT in all English language skills rather than LOT. The positive finding on achieving students' high level of thinking agrees with the term active learning, as it refers to learners as producers rather than receivers to knowledge (Dhir, Gahwaji, \& Nyman, 2013; Jahnke et al., 2017). It was shown above that iPads apps and functions gave students a power in representing high levels of cognitive skills as in self-assessment, self-feedback and analysing language usage through different apps and sources. This finding agrees with findings by Mango (2015) who revealed that students who used iPads gained a power in being researcher and more independent-learner and played an active role in learning (Thinley, Geva, \& Reye, 2014).

It is thus evident that teachers should customise their instructions with modern technologies and target their role in lessons towards achieving high levels of cognitive skills. It is not clear that teachers are adapting the apps they use on an everyday basis to target higher order thinking skills in their classroom activities. This initially teacher led enhancement of e-technology use can ultimately allow students to be active learners in their own right.

\section{Conclusions}

This study has investigated the impact of using iPads in EFL classes in the light of the cognitive thinking skills of revised Bloom's Taxonomy and how practices in teaching and learning of EFL using iPads represents those 
thinking levels. The results indicate a tendency towards lower order thinking levels skills in all seven language skills. There were flexible and different ways of using iPads that represent all levels, although some absence of iPad roles at higher-order thinking levels. Three roles of teacher and student in driving lessons activities varied in using tablet devices. When students drive the lesson and take more control, they are more likely to move to HOT levels. This requires the teacher to let go of the control of the lesson, to move from the role of sage on the stage at all times in the classroom and allow the students to engage with the iPads in more student driven activities. Our study can help policymakers and English language teachers to take advantage of how iPads are used in higher-order thinking, and how to better integrate iPads in class and deal with the disadvantages of frequent usage of iPads in lower-order thinking. Based on our findings, further studies may consider investigating teaching objectives and exam questions set in teaching and learning practices by iPads to discover to what extent they cover cognitive thinking skills.

\section{References}

Albadry, H. (2017). An Investigation into the Role of Tablet Devices in Facilitating Collaborative Learning in EFL Language Course. International Journal of Emerging Technologies in Learning, 12(4), 39-52. https://doi.org/10.3991/ijet.v12i04.6732

Albiladi, W. S., \& Alshareef, K. K. (2018). The use of tablets in teaching English in Saudi Arabia: Implications and challenges. International Journal of English and Education, 7(3), 281-294.

Al-Bogami, B., \& Elyas, T. (2020). Promoting Middle School Students' Engagement through Incorporating iPad Apps in EFL/ESL Classes. SAGE Open, 10(2), 1-18. https://doi.org/10.1177/2158244020926570

Alharbi, A. A. M. (2020). The Degree of Teaching Knowledge for Saudi EFL Teachers: An Investigation for Madinah EFL Teachers' Perceptions Regarding TPACK Framework. English Language Teaching, 13(10), 99-110. https://doi.org/10.5539/elt.v13n10p99

Almalki, A. (2020). Integration of Technology among Saudi EFL Teachers. English Language Teaching, 13(8), 160-167. https://doi.org/10.5539/elt.v13n8p160

Alnofal, A. I. S. (2018). Cognitive Levels in Saudi EFL Teachers' and Textbook Questions. Journal of Language Teaching and Research, 9(4), 695-701. https://doi.org/10.17507/jttr.0904.04

Alresheed, S., Raiker, A., \& Carmichael, P. (2017). Integrating computer-assisted language learning in Saudi schools: A change model. In Handbook on digital learning for K-12 schools (pp. 369-380), Springer. https://doi.org/10.1007/978-3-319-33808-8_22

Al-Sharef, T. (2018). Pre-service Teachers' Perceptions of the Barriers to ICT Integration in their Future Instructional Practice in a Gulf State (Doctoral dissertation, University Liverpool, UK). https://doi.org/10.17638/03026617

Alsowat, H. (2016). An EFL flipped classroom teaching model: Effects on English language higher-order thinking skills, student engagement and satisfaction. Journal of Education and Practice, 7(9), 108-121.

Anderson, L. W., Krathwohl, D. R., Airasian, P., Cruikshank, K., Mayer, R., Pintrich, P., . . Wittrock, M. (2001). A Taxonomy for Learning, Teaching and Assesing: a Revision of Bloom's Taxonomy. New York. LongmanPublishing.

Baghaei, S., Bagheri, M. S., \& Yamini, M. (2020). Analysis of IELTS and TOEFL reading and listening tests in terms of Revised Bloom's Taxonomy. Cogent Education, 7(1), 1-23. https://doi.org/10.1080/2331186X.2020.1720939

Barari, N., RezaeiZadeh, M., Khorasani, A., \& Alami, F. (2020). Designing and validating educational standards for E-teaching in virtual learning environments (VLEs), based on revised Bloom's taxonomy. Interactive Learning Environments, 1-13. https://doi.org/10.1080/10494820.2020.1739078

Beetham, H., \& Sharpe, R. (2013). Rethinking pedagogy for a digital age: Designing for 21st century learning. routledge.

Bloom, B. S., Englehart, M. B., Furst, E. J., Hill, W. H., \& Krathwohl, O. R. (1956). Taxonomy of educational objectives: The classification of educational goals. Handbook 1: The cognitive domain. New York: Longman.

Bower, M. (2017). Design of technology-enhanced learning: Integrating research and practice: Emerald Group Publishing. https://doi.org/10.1108/9781787141827 
Braun, V., \& Clarke, V. (2006). Using thematic analysis in psychology. Qualitative research in psychology, 3(2), 77-101. https://doi.org/10.1191/1478088706qp063oa

Bybee, R. W., \& Fuchs, B. (2006). Preparing the 21st century workforce: A new reform in science and technology education. Journal of Research in Science Teaching, 43(4), 349-352. https://doi.org/10.1002/tea.20147

Cavus, N. (2015). Distance learning and learning management systems. Procedia-Social and Behavioral Sciences, 191(2), 872-877. https://doi.org/10.1016/j.sbspro.2015.04.611

Cherner, T., \& Curry, K. (2017). Enhancement or transformation? A case study of preservice teachers' use of instructional technology. Contemporary Issues in Technology and Teacher Education, 17(2), 268-290.

Chun, D., Kern, R., \& Smith, B. (2016). Technology in language use, language teaching, and language learning. The Modern Language Journal, 100(S1), 64-80. https://doi.org/10.1111/modl.12302

Cochrane, T., Narayan, V., \& Oldfield, J. (2013). iPadagogy: Appropriating the iPad within pedagogical contexts. International Journal of Mobile Learning and Organisation, 7(1), 48-65. https://doi.org/10.1504/IJMLO.2013.051573

Creswell, J. W. (2013). Qualitative inquiry: Qualitative inquiry and research design. In: Los Angeles, California: Sage publications.

Çubukçu, Z. (2012). Teachers' evaluation of student-centered learning environments. Education, 133(1), 49-66.

Culén, A. L., \& Gasparini, A. (2011). iPad: a new classroom technology? A report from two pilot studies. INFuture Proceedings, 3(2), 199-208.

Curtin, R., \& Tarnow, M. (2013). Integrating iPad Technology in Learning Experiences: A Case Study of an iPad Pilot Project. In Learning Management Systems and Instructional Design: Best Practices in Online Education (pp. 192-207), IGI Global. https://doi.org/10.4018/978-1-4666-3930-0.ch010

Dhir, A., Gahwaji, N. M., \& Nyman, G. (2013). The role of the iPad in the hands of the learner. J. UCS, 19(5), 706-727.

Dias, L., \& Victor, A. (2017). Teaching and learning with mobile devices in the 21 st century digital world: Benefits and challenges. European Journal of Multidisciplinary Studies, 2(5), 339-344. https://doi.org/10.26417/ejms.v5i1.p339-344

Eber, P. A., \& Parker, T. S. (2007). Assessing Student Learning: Applying Bloom's Taxonomy. Human Service Education, 27(1), 45-53.

Elfatihi, M. (2017). A rationale for the integration of critical thinking skills in EFL/ESL Instruction. Higher Education of Social Science, 12(2), 26-31.

Ellis, G., \& Brewster, J. (2014). Tell it again! the storytelling handbook for primary english language teachers. British Council London.

Gabarre, C., Gabarre, S., Din, R., Shah, P. M., \& Karim, A. A. (2014). iPads in the foreign language classroom: A learner's perspective. $3 \mathrm{~L}$ : Language, Linguistics, Literature $\mathbb{R}, \quad 20(1), \quad 115-128$. https://doi.org/10.17576/3L-2014-2001-09

Gitsaki, C., Robby, M. A., Priest, T., Hamdan, K., \& Ben-Chabane, Y. (2013). A research agenda for the UAE iPad initiative. Learning and Teaching in Higher Education: Gulf Perspectives, 10(2), 1-15. https://doi.org/10.1109/HICSS.2012.390

Goh, C., \& Taib, Y. (2006). Metacognitive instruction in listening for young learners. ELT journal, 60(3), 222-232. https://doi.org/10.1093/elt/ccl002

Henderson, S., \& Yeow, J. (2012). iPad in education: A case study of iPad adoption and use in a primary school. Paper presented at the System science (hicss), 2012 45th hawaii international conference on System Sciences, Maui HI, 2012. https://doi.org/10.1109/HICSS.2012.390

Homma, J. E. B. (2015). Learner autonomy and practice in a flipped EFL classroom: Perception and perspectives in new digital environments.

International experiences in implementing tablet devices in education. (2015, October 25). New Education News.

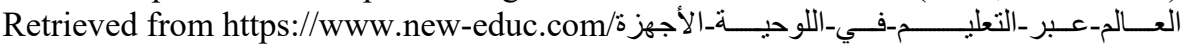


Jahnke, I., Bergström, P., Mårell-Olsson, E., Häll, L., \& Kumar, S. (2017). Digital didactical designs as research framework: iPad integration in Nordic schools. Computers \& Education, 113, 1-15. https://doi.org/10.1016/j.compedu.2017.05.006

Karsenti, T., \& Fievez, A. (2013). The iPad in education: uses, benefits, and challenges. A survey of 6057 students and 302 teachers in Quebec, Canada. Montreal, QC: Crifpe.

Keane, T., Keane, W. F., \& Blicblau, A. S. (2016). Beyond traditional literacy: Learning and transformative practices using ICT. Education and Information Technologies, 21(4), 769-781. https://doi.org/10.1007/s10639-014-9353-5

Khorsand, N. (2009). Cognitive Levels of Questions Used by Iranian EFL Teachers in Advanced Reading Comprehension Tests. Online Submission.

King, A. (1993). From sage on the stage to guide on the side. College teaching, 41(1), 30-35. https://doi.org/10.1080/87567555.1993.9926781

Köksal, D., \& Ulum, Ö. G. (2018). Language assessment through Bloom's Taxonomy. Journal of language and linguistic studies, 14(2), 76-88.

Krathwohl, D. R. (2002). A revision of Bloom's taxonomy: An overview. Theory Into Practice, 41(4), $212-218$. https://doi.org/10.1207/s15430421tip4104_2

Lawrence, B. A. (2016). iPad Acceptance by English Learners in Saudi Arabia. English Language Teaching, 9(12), 34-46. https://doi.org/10.1207/s15430421tip4104_2

Lu, Y.-H., Ottenbreit-Leftwich, A. T., Ding, A.-C., \& Glazewski, K. (2017). Experienced iPad-using early childhood teachers: Practices in the one-to-one iPad classroom. Computers in the Schools, 34(1-2), 9-23. https://doi.org/10.1080/07380569.2017.1287543

Mango, O. (2015). iPad use and student engagement in the classroom. Turkish Online Journal of Educational Technology-TOJET, 14(1), 53-57.

Marshadi, E. (2011). Enhancing early recognition of children in the city of Babel. Basic Education Library, 12(1), 13-22.

McKnight, K., O'Malley, K., Ruzic, R., Horsley, M. K., Franey, J. J., \& Bassett, K. (2016). Teaching in a digital age: How educators use technology to improve student learning. Journal of research on technology in education, 48(3), 194-211. https://doi.org/10.1080/15391523.2016.1175856

Mizbani, M., \& Chalak, A. (2017). Analyzing Listening and Speaking Activities of Iranian EFL Textbook Prospect 3 through Bloom's Revised Taxonomy. Advances in Language and Literary Studies, 8(3), 38-43. https://doi.org/10.7575/aiac.alls.v.8n.3p.38

Moon, A. L., Wold, C. M., \& Francom, G. M. (2017). Enhancing reading comprehension with student-centered iPad applications. TechTrends, 61(2), 187-194. https://doi.org/10.1007/s11528-016-0153-1

Neumann, M. M., Merchant, G., \& Burnett, C. (2020). Young children and tablets: The views of parents and teachers. Early Child Development and Care, 190(11), 1750-1761. https://doi.org/10.1080/03004430.2018.1550083

Rich, P. (2012). Inside the black box: revealing the process in applying a grounded theory analysis. Qualitative Report, 17, 49.

Richards, J. C., \& Burns, A. (2012). The Cambridge guide to pedagogy and practice in second language teaching. Cambridge University Press.

Rim, B. (2019). Teachers' use of technology to enhance EFL learners' critical thinking skills case study: Biskra Secondary School Third Year Learners, Algeria. International Journal of Language Academy, 7(2), 279. https://doi.org/10.18033/ijla.4157

Robyn, E. (2014). Bloom's taxonomy. Denver, CO: Expert Beacon. Retrieved from https://expertbeacon.com/blooms-taxonomy/\#.XAapFtszaM9

Saudi Today. (2014, March 1). Alarabiya Net. Retrieved from https://www.alarabiya.net/ar/saudi-today/2014/03/01/75_html

Sharpe, R., Beetham, H., \& De Freitas, S. (2010). Rethinking learning for a digital age: How learners are shaping their own experiences. Routledge. https://doi.org/10.4324/9780203852064 
Tablet devices instead of books in Saudi schools. (2017, April 2). Tech World News. Retrieved from

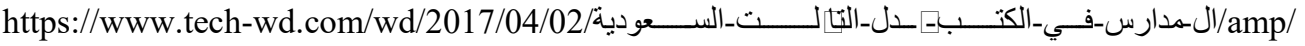

Tehrani, H. T., \& Razali, A. B. (2018). Developing Thinking Skills in Teaching English as a Second/Foreign Language at Primary School. International Journal of Academic Research in Progressive Education and Development, 7(4), 13-29. https://doi.org/10.6007/IJARPED/v7-i4/4755

Thinley, P., Geva, S., \& Reye, J. (2014). Tablets (iPad) for M-learning in the context of social constructivism to institute an effective learning environment. International Journal of Interactive Mobile Technologies (iJIM), 8(1), 16-20. https://doi.org/10.3991/ijim.v8i1.3452

Wu, Y.-T., \& Wang, A. Y. (2015). Technological, Pedagogical, and Content Knowledge in Teaching English as a Foreign Language: Representation of Primary Teachers of English in Taiwan. The Asia-Pacific Education Researcher, 24(3), 525-533. https://doi.org/10.1007/s40299-015-0240-7

Zamawe, F. C. (2015). The implication of using NVivo software in qualitative data analysis: Evidence-based reflections. Malawi Medical Journal, 27(1), 13-15. https://doi.org/10.4314/mmj.v27i1.4

\section{Copyrights}

Copyright for this article is retained by the author(s), with first publication rights granted to the journal.

This is an open-access article distributed under the terms and conditions of the Creative Commons Attribution license (http://creativecommons.org/licenses/by/4.0/). 